\title{
$\checkmark$ Research Square \\ Ethnobotany of Bajiru (Chrysobalanus Icaco L.) In a Coastal Vegetation of Southeastern Brazil
}

\section{Viviane Stern Fonseca-Kruel ( $\nabla$ vfonseca@jbrj.gov.br )}

Jardim Botanico do Rio de Janeiro https://orcid.org/0000-0002-1326-4975

\section{Maria Eduarda Rodrigues Neves}

Jardim Botanico do Rio de Janeiro

Dorothy Sue Dunn de Araujo

Jardim Botanico do Rio de Janeiro

Ghillean T. Prance

Royal Botanic Gardens Kew

\section{Research}

Keywords: Ethnobotany, traditional knowledge, Massambaba Restinga, artisanal fishermen, Atlantic forest, diabetes

Posted Date: January 21st, 2020

DOI: https://doi.org/10.21203/rs.2.21438/v1

License: (1) (1) This work is licensed under a Creative Commons Attribution 4.0 International License. Read Full License 


\section{Abstract}

Background: Chrysobalanus icaco L. (Chrysobalanaceae) is a native but not endemic shrub species from Brazil. It is known as: abajirú, ajuru, bajirú, guajurú. There are ancient reports of edible fruits and leaves used in traditional medicine, mainly by the artisanal fishing communities of the Brazilian coast. It occurs especially in the coastal sand plains, situated between the Atlantic Ocean and the rainforest. However, in the last two decades this vegetation has been suffering strong anthropic pressures, which has led to the suppression of vegetation cover. This fact has impacted both the maintenance of plants and cultural diversity associated with it. Our study aimed to investigate current ethnobotanical knowledge about bajiru, an important species for the treatment of diabetes and recognized in the artisanal fishing communities of Southeastern Brazil to support conservation actions and sustainable management plan.

Methods: This study was conducted with the artisanal fishermen community, near the Restinga de Massambaba, Brazilian costal vegetation and was supported by the signature and consent of all the fishermen involved. The collection of ethnobotanical information was performed using snowball technique, seeking artisanal fishermen who hold local knowledge, conversations and informal interviews based on rapport, semi-structured interviews and free listing. The Anthropac 4.0 software was used to calculate the highest citation frequency and highest salience among the repertoire of useful species indicated in the free listing. Complementary techniques were used: free walking with local experts for information triangulation and to collect botanical material. We used the Informant Consensus Factor (ICF) and Fidelity level (FL).

Results: Interviews were conducted with 42 artisanal fishermens and bajiru was a preferred and useful species of current relevance (indicated by 32 of 42 fishermen). Its leaves are still used for diabetes treatments and with representative value of the informants' consensus in the studied sample $($ IFC $=0.78)$ and the level of fidelity of this use information $(F L=1)$.

Conclusions: In our discussion we highlight the importance of bajiru as a potential for future studies for diabetes. Should the use of bajiru increase comercially greater plans for the conservation and possible cultivation of this specie will be needed.

\section{Background}

\section{Ethnobotany of bajiru (Chrysobalanus icaco L.) in a coastal vegetation of Southeastern Brazil}

Chrysobalanus icaco L. (Chrysobalanaceae) is a native but not endemic shrub species from Brazil, that occurs on the tropical coast from Florida (USA) to Southeast Brazil, in the coastal vegetation of countries in northern South America, Central America, Mexico and the west coast of Africa [28, 35]. In Brazil, it is known as: abajirú, abajurú, ajuru, abajerú, bajerú, bajirú, guajurú $[28,13,10]$, occurring especially in the restingas - sandy coastal plains of quaternary origin, situated between the Atlantic Ocean and tropical rainforest [19]. For the last two decades this vegetation has been suffering strong anthropic pressures, a fact that has led to the loss of large areas of native vegetation [32], as well as of local knowledge related 
to plant and cultural diversity. Although $C$. icaco is not yet on the List of Endangered Species of Flora of Brazil [12], it occurs in the Atlantic Forest Biome in restinga areas (an environment associated with this biome), a biodiversity hotspot and one of the most endangered of Brazil, with only $12.4 \%$ of its original area $[22,36]$. In these areas there is still local knowledge, such as that of artisanal fishermen, about the current and past use of ripe fruits of $C$. icaco, widely consumed in natura, as well as their leaves for making an antidiabetic infusion $[13,10,9,18]$. It is noteworthy that this plant is still suffering strong plant extractivism, since fertile branches or not, are extensively marketed in fairs and markets in the city of Rio de Janeiro [34].

However, as this plant occurs along part of the long Brazilian coast (ca. 7,000 km) there are still few studies detailing the ethnobotanical uses of $C$. icaco $[13,18]$, despite extensive literature proving its food potential, as fruit whose nutritional value is relevant, rich in minerals - chromium, selenium, calcium and iron [1] and hypoglycemic properties in its leaves, being used in traditional medicine of Brazil [31, 30, 38]. We also highlight records for leukorrhea, bleeding and chronic diarrhea treatment [26, 24], antimicrobial activity [11], presence of triterpenes in their leaves, leading to antitumor activity in leukemia cell lines [11]. The proteomic characterization of the aqueous extract of $C$. icaco leaves confirmed the presence of enzymes involved in the glucose metabolic pathway [25]. The fruits studied by [39] indicated antioxidant activity in rats, in addition to reducing inflammation and DNA damage [40]. An extract of, $C$. icaco roots from material collected in Central Africa had two diterpenes, one of which showed inhibitory action on HIV-1 infected cells in vitro [16].

In this sense, this study aims to investigate current ethnobotanical knowledge about bajiru, the local importance to generating integrated knowledge the information already recorded in other scientific studies, especially for diabetes because the use of plants to treat diabetes in Brazil, which ranks fourth among countries with the highest number of diabetics [4]. These results may be useful in conservation actions and sustainable management plans in the restingas areas where this species occurs. With this, we present a case study on the ethnobotanical knowledge of bajiru in a community of artisanal fishermen in southeastern Brazil.

\section{Methods}

This study was conducted with the artisanal fishermen community residing near the Restinga de Massambaba (RM), in the municipality of Arraial do Cabo $\left(22^{\circ} 56^{\prime} \mathrm{S}\right.$ and $\left.42^{\circ} 05^{\prime} \mathrm{W}\right)$, on the southeastern coast of Brazil [2]. Artisanal fishermen have lived in this area for over 150 years and are descended from European settlers, especially Portuguese, along with indigenous peoples [7]. Arraial do Cabo until 1950 was a small fishermen village, whose social identity and economic livelihoods were based on fishing [27]. This area was recognized by the tradition of "trawl fishing" The Arraial do Cabo Marine Extractive Reserve (RESEX-Mar) and currently, part of this territory is part of the recent environmental protection area of the State of Rio de Janeiro, the Costa do Sol State Park (under the responsibility of the State Environmental Institute - INEA, State Decree No. 42.929 of April 18, 2011). There are currently 1,600 artisanal fishermen 
families associated with RESEX-Mar, distributed in the fishing territories, along the RM and near the Araruama Lagoon [6], whose predominant vegetation is restinga.

Ethics and Data collection - To carry out this study the code of the International Society of Ethnobiology Code of Ethics was followed [17], we emphasized that the research was always supported by the signature and consent of the fishermen involved. The data analyzed here refer to the database of the project "Ethnobotany in the Center of Plant Diversity of Cabo Frio, Rio de Janeiro, Brazil", with data collected from artisanal fishers, from 2000 to 2011, currently registered with the largest Project: "Restinga de Massambaba: Vegetation, Flora, Propagation and Uses", in the National System of Genetic Heritage Management and Associated Traditional Knowledge - SISGEN (no. A6B205D). However, the referred project already had previous authorizations for the collection of botanical material and for access to the traditional knowledge in Brazil, such as: National Council of Genetic Heritage (CGEN - n 02000.01698 / 2006-18) and the Institut of State Environmen - INEA - $n^{\circ} 021 / 2010$ ).

The collection of ethnobotanical information was performed using snowball technique [5], seeking artisanal fishermen (resident for more than 20 years or native (born) in areas adjacent to the MR) who hold local knowledge, visits, conversations and informal (individual) interviews based on rapport [29, 20], individual, semi-structured interviews and the free listing technique [42], whose main questions were: What are the medicinal plants you know in the restinga? What are the medicinal plant parts and how are they used? We asked the interviewee to list medicinal plants to infer preferred species [3], and the cognitive domain and ranking of $C$. icaco in the study area. Data analysis was performed using the Anthropac 4.0 program to calculate the plant with the highest citation frequency (OF) and highest salience (OS), which led us to bajiru as number one in the ranking (Borgati 1996). Walking in the restinga vegetation were conducted individually with local specialists for information triangulation and mainly to collect testimonial botanical material that was deposited in RB Herbarium.

From the collected data two additional statistical analyzes were then made: The Informant Consensus Factor (ICF) [37] shows the agreement among the informants about the specific use analyzed, being its maximum value one, and is calculated as follows:

$$
\mathrm{ICF}=\frac{\mathrm{Nur}-\mathrm{Nt}}{(\mathrm{Nur}-1)}
$$

Nur $=$ total number of citations of plants within the medicinal category, $\mathrm{Nt}=$ total number of species within the category; Fidelity level (FL) [15] is used in studies with medicinal plants to analyze the agreement of use for a specific therapeutic indication among the interviewees; and is calculated as follows:

$$
\mathrm{FL}=\left(\frac{\mathrm{Ip}}{\mathrm{Iu}}\right) \times 100 \%
$$

Ip = number of informants who cited the use of the species for such therapeutic indication; lu = total number of informants who cited the species for a specific purpose analyzed. 


\section{Results}

Ethnobotanical information was obtained from 42 local specialists, artisanal fishermen, aged between 20 and 90 years, who indicated 44 medicinal species in RM, with 194 citations of uses. From the 44 medicinal species a group with five species of medicinal turned out to be the most relevant, Chrysobalanus icaco L. (bajiru), Schinus terebenthifolia Raddi (aroeira), Eugenia uniflora L. (pitanga), Baccharis crispa Spreng. (carqueja) and Cestrum axillare Vell. (canema).

Bajiru was recognized by 32 of 42 local specialists as a medicinal resource both in the past and present. All of them indicated the use of its leaves as a hypoglycemic agent for diabetes and in natura fruits as a local food resource.

We analyzed the medicinal use of bajiru in the group of local specialists studied, and through the Informant Consensus Factor (ICF $=0.78$ ), it was possible to observe the consensus on this form of use and its local relevance. We also calculated the level of fidelity, which demonstrated the relevance of the specific use of bajiru leaves in the treatment of diabetes $(F L=1)$.

The results of the interviews showed that there is no determined period for resource collection, leaves for medicinal use and / or fruits for food, because there is availability throughout the year. In this sense it was pointed out that there is no limiting factor regarding the availability of the resource by seasonality, but pointed out that native bajiru populations have been decreasing due to the loss of natural habitat mainly caused by pressure of real estate speculation (house constructions or condominiums near the beach).

In ethnobotanical studies conducted in RM, it was observed that bajiru is one of the preferred species due to its result in the analysis of Anthropac ( $\mathrm{FR}=74,5 ; \mathrm{SI}=0,527$ ), for its multiple use (food and medicinal), as well as being reported as a resource available. However, there was no direct relationship of this plant as a source of financial resources for the local population, but during the interviews the pressure that bajiru population suffer from predatory extraction, carried out by outsiders that collects the leaves for commercialization in fairs and markets of the state of Rio de Janeiro was reported.

The frequency of reports such as those mentioned below during interviews with artisanal fishermen is highlighted: "... almost every family has diabetes ..."; "... a week yes and the other not, take a portion of bajiru leaf and cook ... take three times a day ...".

\section{Discussion}

Restinga vegetation has been studied by different authors, and the use and / or potential of plant resources in these areas has been recorded, such as $[13,21]$, who studied useful species associated with local knowledge and local traditions of fishermen from Arraial do Cabo and Ilha do Cardoso, respectively. 
However, the present study emphasizes the importance of conserving biological diversity as well as traditional local knowledge about the restinga vegetation. Bajiru in the RM has been shown to be a source of potential medicinal resource, and especially associated with a worldwide relevant therapeutic target diabetes. This result was also highlighted in studies conducted with fishermen communities along the Brazilian coast, such as in Pará and Rio de Janeiro [13, 10,9], as well as in studies of markets in RJ [34].

However, since 1970/80 RM has been suffering from the rapid loss of its vegetation cover over the years, especially from the strong pressure of unsustainable tourism and estate speculation [32], that has been changing and causing environmental and social collapse, due to the loss of part of vegetation cover and social/cultural activities.

Such vegetation demonstrates that it still has great potential for groups of humans living in its vicinity, especially as observed in the present study and others related to the current health and food resources $[13,33,14]$.

There was no direct relationship of this plant as a source of financial resources for the local population, which can be harvested for different purposes such as artisanal, fishing traps, without resulting in a decrease in diversity when based on traditional practices [23]. However, such activities have been carried out by people from other municipalities of Rio de Janeiro who extract their leaves and sell in markets (e.g. Mercadão de Madureira) of the metropolitan region of Rio de Janeiro [34]. This authors [34] showed problems of incorrect identification of $C$. icaco, which is sometimes substituted by leaves of other species such as Eugenia rotundifolia Casar. (current name E. astringens) being sold as bajiru. This may result of difficulties related to environmental monitoring of restinga resources, since $E$. astringens has wider distribution in RJ state and lower enforcement pressure.

The lack of studies on bajiru cultivation and management associated with the risk of areas in which the species grows naturally leads to a risky situation regarding its conservation. This study showed that $100 \%$ of bajiru use citations refer to its medicinal use for diabetes, which demonstrates the importance of such a plant for local communities as a form of treatment. Therefore, in addition to the risk of bajiru conservation, there is a risk of loss of traditional medicinal use in populations at restinga areas.

According to [4], around 425 million people worldwide, $8.8 \%$ of adults between the ages of 20 and 79 were estimated to have diabetes. Brazil ranked fourth among the countries with the highest number of diabetics in this estimate, with 12.5 million diagnosed, $8.1 \%$ of its total population, and the projection of over 20.3 million diagnosed by 2045 [4]. In the state of Rio de Janeiro, its prevalence was $10.4 \%$ in the population aged 18 years and over [41]. This demonstrates the need for studies involving measures to treat this disease in constant progress in global society.

Thus, bajiru has great potential for broader studies associating the traditional knowledge of its medicinal use, cultivation and management of the species, besides the conservation of the areas in which it occurs, in order to ensure its preservation as a potential source of broader medicinal use against diabetes. 
Should the use of bajiru increase comercially greater plans for the conservation and possible cultivation of this species will be needed.

\section{Conclusions}

Popularly known by similar names, bajiru, bajuru, abajeru, ajiru, $C$. icaco is a valuable botanical source due to its uses of fruits as available food and especially leaves in traditional medicine, as observed by the Arraial do Cabo artisanal fishermen, being used to treat diabetes. Several scientific studies corroborate and validate its importance as a hypoglycemic plant, besides pointing out other bioactivities.

\section{List Of Abreviations}

ICF - Informant Consensus Factor

FL - Fidelity level

RM - Restinga de Massambaba

RESEX-Mar - Arraial do Cabo Marine Extractive Reserve

INEA - State Environmental Institute

CGEN - National Council of Genetic Heritage

RB - Rio de Janeiro Botanical Garden Herbarium

SISGEN - National System of Genetic Heritage Management and Associated Traditional Knowledge

VK - Viviane Kruel

DA - Dorothy Araujo

GP - Ghillean Prance

MER - Maria Eduarda Rodrigues

\section{Declarations}

\section{Ethics approval and consent to participate}

For this study, the Code of Ethics of the International Society of Ethnobiology (Code ISE 2006) was followed. It is emphasized that the research was always supported by the signature and consent of the fishermen involved. The data analyzed here refer to the database of the project "Ethnobotany in the Center of Plant Diversity of Cabo Frio, Rio de Janeiro, Brazil", with data collected from artisanal fishers, from 2000 to 2011, currently registered with the largest Project: "Restinga de Massambaba: Vegetation, 
Flora, Propagation and Uses", in the National System of Genetic Heritage Management and Associated Traditional Knowledge (SISGEN no. A6B205D). However, the referred project already had previous authorizations for the collection of botanical testimonial material and for access to the traditional knowledge of the national and state governmental of Brazil, such as: National Council of Genetic Heritage (CGEN - $n^{\circ} 02000.01698$ / 2006-18) and the Institut of State Environment / Instituto Estadual do Meio Ambiente - INEA (INEA nº 021/2010; E-07/502.887/2010).

Consent for publication: Not applicable.

Availability of data and materials: Not applicable.

Competing interests: The authors declare that they have no competing interests.

\section{Funding}

We had no specific funding for this manuscript. This result is part of the doctoral thesis of the first author, in the Postgraduate course of the National School of Tropical Botany.

\section{Authors' contributions}

VK, DA, GP conceived and designed the study. VK, MER conducted the data collection and/or analyzed the data. VK participated in the design and coordination. VK, DA, GP identified the plant collected. VK and $\mathrm{GP}$ revised the manuscript. All authors read and approved the final manuscript.

\section{Acknowledgment}

We thank the friendship and knowledge exchange of artisanal fishermen of Arraial do Cabo, especially "Mestre Chonca" (Wilson da Silva). This article is part of the first author's doctorate (2011), from the Graduate Program in Botany of the National School of Tropical Botany (ENBT - Escola Nacional de Botânica Tropical).

\section{References}

1. Aguiar TM, Sabaa-srur, AUO, Samico, GF. Nutritional Potential and Physicochemical Properties of Coco plum. Pesquisa Agropecuária Tropical, 2011; 41:102-109.

2. Araujo, DSD, Sá CFC, Pereira, JF, Garcia DS, Ferreira, MV, Paixão RJ et al. Área de Proteção Ambiental de Massambaba, Rio de Janeiro: caracterização fitofisionômica e lista florística. Rodriguésia. 2009; 60:67-96.

3. Albuquerque UP, Lucena RFP, Cunha LVF. Métodos e técnicas na pesquisa etnobiológica e etnoecológica. Recife: NUPEEA; 2010.

4. Atlas IDF. Diabetes no Brasil. 2019. https://www.sosma.org.br/wpcontent/uploads/2019/07/RA_SOSMA_2018_DIGITpdf. Accessed 10 Oct 2019. 
5. Bailey K. 1994. Methods of social research. New York: The Free Press; 1994.

6. Barreto OS, Farias R, Lasmar V. Relatos das Ações Institucionais Articuladas entre o ICMBio e demais Parceiros para a Salvaguarda do Patrimônio Cultural e Natural em Arraial do Cabo - RJ. In: Ribeiro, SMP, Araujo AF (orgs). Paisagem, Imaginário e Narratividade. Olhares transdisciplinares e novas interrogações da Psicologia Social. 1ª . Ed. São Paulo: Zagodoni. 2015. p.218-225.

7. Britto RCC. Modernidade e tradição - construção da identidade social dos pescadores de Arraial do Cabo. Eduff, Niterói;

8. Borgatti SP. ANTHROPAC 0 Methods Guide. Analytic Technologies, Natick, MA; 1996.

9. Carneiro DB, Barboza MSL, Menezes PM. Plantas nativas úteis na comunidade na Vila dos Pescadores da Reserva Extrativista Marinha Caeté-Taperaçu, Pará, Brasil. Acta Botanica Brasilica. 2010; 24:1027-1033.

10. Coelho-Ferreira M. Medicinal knowledge and plant utilization in an Amazonian coastal community of Marudá, Pará State (Brazil). J Ethnopharmacol. 2009; 126:159-175.

11. Fernandes J, Castilho ROC, Wagner-Souza MRK., Kaplan MAC, Gattass CR. Pentacyclic triterpenes from Chrysobalanaceae species: cytotoxicity on multidrug resistant and sensitive leukemia cell lines. Cancer Lett. 2003; 190:165-169.

12. Flora do Brasil 2020 em construção. Jardim Botânico do Rio de Janeiro. 2019. http://floradobrasil.jbrj.gov.br/. Accessed 10 Sept 2019.

13. Fonseca-Kruel VS, Peixoto AL. Etnobotânica na Reserva Extrativista Marinha de Arraial do Cabo, RJ. Acta Botanica Brasilica. 2004;18:177-190.

14. Fonseca-Kruel VS. Etnobotânica nas restingas no Centro de Diversidade Vegetal de Cabo Frio, Rio de Janeiro, Brasil. Tese (Doutorado) - Instituto de Pesquisas Jardim Botânico do Rio de Janeiro, Escola Nacional de Botânica Tropical, Rio de Janeiro; 2011. 192.

15. Friedman J, Yaniv Z, Dafni A, Plewith, D. A preliminary classification of the healing potencial of medicinal plants, based on a rational analysis of an ethnopharmacological field survey among bedouins in the Negev desert, Israel. J Ethnopharmacol. 1986; 16:275-287.

16. Gustafson,KR, Munrol MHG, Blunt JW, Cardellina JH, McMahon JB, Gulakowski, RJ, et al. HIV Inhibitory Natural Products. 3. Diterpenes from Homalanthus acuminatus and Chrysobalanus icaco. Tetrahedron. 1991; 41: 4547-4554.

17. International Society of Ethnobiology Code of Ethics (with 2008 additions). International Society of Ethnobiology. 2006. http://ethnobiology.net/code-of-ethics/. Accessed 20 Oct 2018.

18. Lopes LCM, Lobão AQ. Etnobotânica em uma comunidade de pescadores artesanais no litoral norte do Espírito Santo, Brasil. Mus. Biol. Mello Leitão. 2013; 32: 29-52.

19. Marques M, Swaine MD, Liebsch D. Diversity distribution and floristic differentiation of the coastal lowland vegetation: implications for the conservation of the Brazilian Atlantic Forest. Biodiversity and Conservation. 2010; 20: 153-168. 
20. Martin GJ. Etnobotánica - Manual de métodos: manuales de conservación. Série Pueblos y Plantas 1, WWF. Ed. Nordan-Comunidad, Uruguay; 2000.

21. Miranda TM, Hanazaki N. Conhecimento e Uso de Recursos Vegetais de Restinga por Comunidades das Ilhas do Cardoso (SP) e de Santa Catarina (SC), Brasil. Acta Botanica Brasilica. 2008; 22:203215.

22. Myers N, Mittermeier RA, Mittermeier CG, Fonseca GAB, Kent J. Biodiversity hotspots for conservation priorities. Nature 2000; 403:853-858.

23. Oliveira FC, Hanazaki N. Ethnobotany and ecological perspectives on the management and use of plant species for a traditional fishing trap, southern coast of São Paulo, Brazil. J Environmental Management. 92: 1783-1792.

24. Paulo AS, Balassiano IT, Silva NH, Castilho RO, Kaplan MAC, Cabral MC, Carvalho MGC. Chrysobalanus icaco Extract for antiangiogenic potential observation. Internat J Mol Med 2000; 5: 667-669.

25. Pedrete RA, Hauser-Davis, Moreira JC. Proteomic characterization of medicinal plants used in the treatment of diabetes, International Journal of Biological Macromolecules. 2019; 140:294-302.

26. Pio Corrêa M. Dicionário de Plantas Úteis do Brasil e das exóticas cultivadas. Rio de Janeiro: Imprensa Nacional; 1926.

27. Prado SM. Da anchova ao salário mínimo: uma etnografia sobre injunções de mudança social em Arraial do Cabo, RJ. Eduff, Niterói; 2002.

28. Prance GT. Flora Neotropica. Monograph n¹0. New York: Hafner Publishing; 1972.

29. Prance GT, Baleé W, Boom BM, Carneiro RL.Quantitative ethnobotany and the case for conservation in Amazônia. Conservation Biology. 1987; 1:296-310.

30. Presta GA, Santos-Filho SD, De Paoli S, Giani TS, Maiworm, Al, Brandão-Neto, J., Medeiros, AC., Fonseca AS, Bernardo-Filho M. Effects of Chrysobalanus icaco on the labeling of blood constituents with technetium-99m and on the shape of the red blood cells. Brazilian Archives of Biology and Technology. 2007; 50:145-152.

31. Presta GA, Pereira NA. Activity of abagerú (Chrysobalanus icaco, Chrysobalanaceae) in experimental models to the study of hypoglycemiant plants. Rev Bras Farm. 1987; 68: 91-101.

32. Rocha CFD, Bergallo HG, Van Sluys M, Alves MAS, Jamel CE. The remnants of restinga habitats in the brazilian Atlantic Forest of Rio de Janeiro state, Brazil: Habitat loss and risk of disappearance. J. Biol. 2007; 67: 263-273.

33. Santos MG, Fevereiro PC, Reis GL, Barcelos JI. Recursos vegetais da Restinga de Carapebus, Rio de Janeiro, Brasil. Rev. Biol. Neotrop. 2009; 6:35-54.

34. Silva IM \& Peixoto AL. Abajurú (Chrysobalanus icaco and Eugenia rotundifolia Casar.) commercialized in Rio de Janeiro, Brazil. Brazilian Journal of Pharmacognosy. 2009; 19: 325-332.

35. Smith N, Mori SA, Henderson A, Stevenson DW, Heald SV. Flowering plants of the neotropics. 1st ed. Princeton and Oxford published in association with The New York Botanical Garden. 2004. 
36. SOS Mata Atlântica. Relatório anual 2018. https://www.sosma.org.br/wpcontent/uploads/2019/07/RA_SOSMA_2018_DIGIpdf. Accessed 11 Oct 2019.

37. Troter R., Logan M. Informant consensus: a new approach for identifying potentially effective medicinal plants - L. Etkin (Ed.), Indigenous Medicine and Diet: Biobehavioural Approaches, Redgrave Bedford Hills, New York, 1986. p. 91-112.

38. Vargas CE, Mendes MF, Azevedo DA, Pessoa FLP, Ullera AC. Extraction of the essential oil of abajeru (Chrysobalanus icaco) using supercritical CO². The Journal of Supercritical Fluids. 2010; 54: 171177.

39. Venancio VP, Gomes UH, Daysy T, Darin C, Marques JD, Mercadante MC, et al. Guajiru (Chrysobalanus icaco) Fruit Showed Antioxidant Activity in Kidneys of Wistar Rats. Free Radical Biology and Medicine. 2012; 53-S89-S89.

40. Venancio VP, Almeida MR, Antunes LMG. Cocoplum (Chrysobalanus icaco) decreases doxorubicininduced DNA damage and downregulates Gadd45a, II-1 $\beta$, and Tnf-a in vivo. Food Research International. 2018; 5: 996-1002.

41. Vigitel Brasil. Vigilância de fatores de risco e proteção para doenças crônicas por inquérito telefônico : estimativas sobre frequência e distribuição sociodemográfica de fatores de risco e proteção para doenças crônicas nas capitais dos 26 estados brasileiros e no Distrito Federal em 2016 / Ministério da Saúde, Secretaria de Vigilância em Saúde, Departamento de Vigilância de Doenças e Agravos não Transmissíveis e Promoção da Saúde. - Brasília: Ministério da Saúde. 2016.

42. Weller SC, Romney AK. Sistematic data collection. Qualitative Research Methods. Vol. 10. University of California, SAGE publications. 1988. 96p.

\section{Figures}

\section{Figure 1}

Native population of Chrysobalanus icaco L. in coastal vegetation, Restinga de Massambaba, in Arraial do Cabo (a), flower (b) and fruit (c, d) details. 